\title{
The Danish Heart Failure Registry
}

This article was published in the following Dove Press journal:

Clinical Epidemiology

25 October 2016

Number of times this article has been viewed

Inge Schjødt'

Anne Nakano ${ }^{2,3}$

Kenneth Egstrup ${ }^{4}$

Charlotte Cerqueira ${ }^{5}$

'Department of Cardiology,

${ }^{2}$ Department of Clinical Epidemiology,

Aarhus University Hospital, ${ }^{3}$ Registry

Support Centre of Clinical Quality

and Health Informatics (West),

Aarhus, ${ }^{4}$ Department of Cardiology,

Odense University Hospital,

Svendborg Hospital, Svendborg,

${ }^{5}$ Registry Support Centre of

Epidemiology and Biostatistics (East),

Research Centre for Prevention and

Health, Capital Region of Denmark,

Glostrup, Denmark
Correspondence: Inge Schjødt Department of Cardiology, Aarhus University Hospital, Palle Juul-Jensens Boulevard 99, 8200 Aarhus N, Denmark

Tel +45 29270177

Fax +45 78452057

Email ingeschj@rm.dk
Aim of database: The aim of the Danish Heart Failure Registry (DHFR) is to monitor and improve the care of patients with incident heart failure (HF) in Denmark.

Study population: The DHFR includes inpatients and outpatients ( $\geq 18$ years) with incident HF. Reporting to the DHFR is mandatory for the Danish hospital departments treating patients with incident HF. Final decision to register a patient in the DHFR is made by a cardiologist to ensure the validity of the diagnosis. Approximately 42,400 patients with incident HF were registered in the DHFR in July 2015.

Main variables and descriptive data: The main variables recorded in the DHFR are related to the indicators for quality of care in patients with incident HF: performance of echocardiography, functional capacity (New York Heart Association functional classification), pharmacological therapy (angiotensin converting enzyme/angiotensin II antagonist inhibitors, beta-blockers, and mineralocorticoid receptor antagonist), nonpharmacological therapy (physical training, patient education), 4-week readmission rate, and 1-year mortality. Furthermore, basic patient characteristics and prognostic factors (eg, smoking and alcohol) are recorded. At the annual national audit in the DHFR, the indicators and standards for good clinical quality of care for patients with HF are discussed, and recommendations are reported back to clinicians to promote quality improvement initiatives. Furthermore, results and recommendations are communicated to the public in an annual report. All standards for the quality indicators have been met at a national level since 2014. Indicators for treatment status 1 year after diagnosis are under consideration (now prevalent HF).

Conclusion: The DHFR is a valuable tool for continuous improvement of quality of care in patients with incident HF in Denmark. Furthermore, it is an important resource for the Danish registry-based HF research.

Keywords: heart failure, registry, quality, indicators, processes of care, variables, quality improvement

\section{Introduction}

The Danish Heart Failure Registry (DHFR) is a nationwide registry established in 2003 as a part of a large nationwide quality improvement initiative aimed at monitoring and improving the quality of care for patients with specific severe diseases, including heart failure (HF). ${ }^{1}$ Reporting to the DHFR is mandatory for all hospital departments treating patients with incident HF. The DHFR achieved complete nationwide coverage in 2005.

\section{Aim of database}

The aim of the DHFR is to monitor and support implementation of evidence-based treatment and care of patients with incident HF, and it is anticipated that it will improve the overall performance in patients with $\mathrm{HF}$. 


\section{Study population}

The DHFR includes data on inpatients and outpatients with incident HF. The HF diagnosis is made by a cardiologist using the criteria of the European Society of Cardiology. ${ }^{2}$ At discharge or at the first outpatient contact, patients with one of the following diagnoses (primary diagnosis) are screened for inclusion in the DHFR: I11.0, I13.0, I13.2, I42.0, I42.6, I42.7, I42.9, I50.0, I50.1, and I50.9. All diagnoses are made in accordance with the International Classification of Diseases 10th edition, which has been used for all admissions and outpatient contacts in Denmark since 1995.

Patients enrolled in the DHFR have to meet the following inclusion criteria: age 18 years or older, a first time hospital contact with $\mathrm{HF}$ as the primary diagnosis, and

- symptoms of HF, usually dyspnea, increased fatigue, fluid retention, and

- objective signs of HF at rest, for example, reduced systolic function and/or diastolic dysfunction/elevated filling pressure and/or

- clinical response to specific HF treatment.

Thus, enrollment in the registry requires both manifestation of symptoms and objective signs of HF at rest and/or response to treatment of HF.

Exclusion criteria are previously verified diagnosis and treatment of HF, isolated right-sided HF, and HF secondary to valvular heart diseases, noncorrectable structural heart diseases, or tachycardia-induced HF (often atrial fibrillation). Furthermore, patients discharged with a diagnosis of acute myocardial infarction and concomitant $\mathrm{HF}$ are not included. These patients will be included if they are later hospitalized with HF or are referred to an outpatient cardiology clinic for treatment of HF.

Only patients with a Danish unique personal identification number (CPR number) are enrolled in the database, allowing accurate linkage between the DHFR and other nationwide administrative registries at the individual level. The decision to register a patient in the DHFR is made by a cardiologist to ensure the validity of the incident $\mathrm{HF}$ diagnosis according to the inclusion and exclusion criteria. By July 2015, the DHFR contained data on $\sim 42,400$ patients with incident HF. Each year, 3,700-3,900 patients with incident HF are registered in the DHFR.

Patients in the DHFR are selected in accordance with the exclusion criteria to establish a homogeneous population with HF. Thus, the DHFR will not reflect the total incidence of HF in the general Danish population due to inclusion and exclusion criteria. Moreover, less-severe cases of HF may be treated in the primary health care sector (general practice) and these cases are not recorded in the DHFR.

\section{Main variables}

The variables recorded in the DHFR are related to basic characteristics, prognostic factors, diagnostic tests, functional capacity (symptom severity), pharmacological therapy, nonpharmacological therapy, readmission, and mortality (Table 1). The quality indicators consist of five processes and two outcome indicators ${ }^{3}$ defined by the DHFR multidisciplinary board to monitor good clinical quality of treatment and care for patients with incident HF. The indicators are echocardiography, New York Heart Association functional classification, medications, physical training, patient education, rate of readmission, and mortality (Table 2). Both the prognostic factors and the evidencebased quality indicators are based on national ${ }^{4}$ and international guidelines. ${ }^{2,5}$

The use of echocardiography and New York Heart Association functional classification, 4-week readmission rate, and 1-year mortality are reported for all patients, whereas the use of angiotensin converting enzyme/angiotensin II antagonist inhibitors and beta-blockers, physical training, and patient education are evaluated in patients with systolic $\mathrm{HF}$ and left ventricular ejection fraction $\leq 40 \%$. The use of mineralocorticoid receptor antagonist is evaluated in patients with left ventricular ejection fraction $\leq 35 \%$.

Until now, the DHFR only contains information about patients with incident HF. At the audit conducted in 2015, the multidisciplinary board decided to supplement the registry with qualitative indicators for treatment status of the patients' treatment 1 year after diagnosis.

Data are registered for patients with HF admitted to hospital or at first outpatient visit by a cardiologist and the nursing staff. The process for registration of data has been developed to ensure data accuracy and for standardizing procedures for all clinicians. ${ }^{6}$

The DHFR board is obliged to ensure that the indicators reflect the quality of HF treatment and that the collection of data is simple and feasible in routine clinical settings. Systematic literature reviews are performed regularly, and the latest review was conducted in 2015 . $^{7}$

Local, regional, and national audits are conducted yearly. Performance data, completeness of registered patients, and variables are reported for each hospital department, region, and at a national level, making comparison of data possible.

At the annual national audit in the DHFR, the indicators and standards for good clinical quality in treatment and care for patients with $\mathrm{HF}$ are discussed and recommendations are 
Table I Main variables in the Danish Heart Failure Registry

\begin{tabular}{|c|c|c|}
\hline Main group & Variable & Description/comments \\
\hline \multirow[t]{8}{*}{ Basic characteristics } & Civil registration number & $\begin{array}{l}\text { Unique personal identification number including date of birth } \\
\text { and sex }\end{array}$ \\
\hline & Age & \\
\hline & Sex & \\
\hline & Status of hospital contact & Inpatient or outpatient \\
\hline & Date of admission/outpatient contact & \\
\hline & Date of discharge & Only hospitalized patients \\
\hline & Status at discharge & Alive or dead \\
\hline & Discharge diagnosis & $\begin{array}{l}\text { III.0, II 3.0, II 3.2, I42.0, I42.6, I42.7, I42.9, I50.0, I50.I, and } \\
\text { I50.9 (ICD-I0) }\end{array}$ \\
\hline \multirow[t]{10}{*}{ Prognostic factors } & Acute myocardial infarction & Yes or no \\
\hline & Stroke & Yes or no \\
\hline & Diabetes & Yes or no \\
\hline & COPD & Yes or no \\
\hline & Hypertension & Yes or no \\
\hline & Serum creatinine $\geq 150 \mu \mathrm{mol} / \mathrm{L}$ & Yes or no \\
\hline & Electrocardiogram & Yes or no \\
\hline & Heart rhythm & SR, AF/AFL, or other \\
\hline & Alcohol intake & $\leq|4 / 2|$ units per week, $>|4 / 2|$ units per week or na \\
\hline & Smoking & Smoker, previous smoker, never smoker, or na \\
\hline Diagnostic test & Echocardiography & $\begin{array}{l}\text { Yes, date for echocardiography or no. If yes, the exact value } \\
\text { for LVEF or LVEF }<25 \%, 25 \% \leq \mathrm{LVEF} \leq 35 \%, 35 \%<\mathrm{LVEF} \\
\leq 40 \%, 40 \%<\mathrm{LVEF}<50 \% \text {, LVEF } \geq 50 \%\end{array}$ \\
\hline Functional capacity & NYHA functional classification & NYHA functional classification I, II, III, IV, or na \\
\hline \multirow[t]{6}{*}{$\begin{array}{l}\text { Pharmacological } \\
\text { therapy }\end{array}$} & $\begin{array}{l}\text { Status of ACE/ATII inhibitor treatment at first } \\
\text { contact }\end{array}$ & Yes or no \\
\hline & Initiation of ACE/ATII inhibitor treatment & Yes and starting date or no \\
\hline & Status of beta-blocker treatment at first contact & Yes or no \\
\hline & Initiation of beta-blocker treatment & Yes and starting date or no \\
\hline & Status of MRA at first contact & Yes or no \\
\hline & Initiation of MRA treatment & Yes and starting date or no \\
\hline \multirow[t]{2}{*}{$\begin{array}{l}\text { Nonpharmacological } \\
\text { therapy }\end{array}$} & Physical training & $\begin{array}{l}\text { Yes and starting date of training in hospital or date for } \\
\text { referral to training in municipality or no }\end{array}$ \\
\hline & Patient education & Yes and starting date or no \\
\hline Readmission & 4-week rate of acute readmission & Yes and date for readmission or no \\
\hline Mortality & I-year mortality & $\begin{array}{l}\text { Alive or dead according to the Danish Civil Registration } \\
\text { System }\end{array}$ \\
\hline
\end{tabular}

Abbreviations: ACE/ATII, angiotensin converting enzyme/angiotensin II antagonist; AF/AFL, atrial fibrillation/atrial flutter; COPD, chronic obstructive pulmonary disease; ICD-I0, International Classification of Diseases IOth edition; LVEF, left ventricular ejection fraction; MRA, mineralocorticoid receptor antagonist; na, not available; NYHA functional classification, New York Heart Association functional classification; SR, sinus rhythm.

reported back to clinicians and communicated to the public in the final annual report. Furthermore, the board decides whether any changes to the quality measures are warranted, and discusses potential new indicators.

In 2014 and 2015, all indicators were met at a national level. ${ }^{8}$ The coverage and completeness of indicator variables and prognostic factors from 2004 to 2015 are shown in Table 3. The completeness of the reported variables for each indicator was between $91 \%$ and $100 \%$ in $2015 .^{8}$

Only patients with a first time primary diagnosis of $\mathrm{HF}$ are included in the registry. We assume that careful screening of the patients by a cardiologist means that virtually all patients included in the database have HF. But a precise validation of the accuracy has not been performed.

The coverage of the DHFR is routinely evaluated by matching data with the administrative data in the Danish National Patient Register, ${ }^{9}$ which includes data on all hospital contacts in Denmark since 1977. A total of $82 \%$ of incident HF cases had been recorded in the DHFR in $2015 .^{8}$ This relatively low coverage may partly be explained by patients being treated for HF in the hospital and, thus, registered accordingly in the Danish National Patient Register, but not meeting the inclusion/exclusion criteria for entry into the DHFR. To obtain high coverage of the registry, a continuous 
Table 2 Process and outcome indicators in the Danish Heart Failure Registry

\begin{tabular}{|c|c|c|c|c|}
\hline Indicator area & Indicator & Time frame & Type & $\begin{array}{l}\text { Standard } \\
(\%)\end{array}$ \\
\hline Echocardiography & $\begin{array}{l}\text { Proportion of patients who undergo } \\
\text { echocardiography }\end{array}$ & $\begin{array}{l}\leq 6 \text { months before or } \leq 7 \text { weekdays after } \\
\text { admission or first outpatient contact }\end{array}$ & Process & $\geq 90$ \\
\hline $\begin{array}{l}\text { NYHA functional } \\
\text { classification }\end{array}$ & $\begin{array}{l}\text { Proportion of patients who undergo NYHA } \\
\text { functional classification }\end{array}$ & $\begin{array}{l}\leq 12 \text { weeks after admission or first } \\
\text { outpatient contact }\end{array}$ & Process & $\geq 90$ \\
\hline \multirow[t]{3}{*}{ Medication } & $\begin{array}{l}\text { Proportion of patients with reduced systolic function } \\
\text { (LVEF } \leq 40 \%) \text { treated with ACE/ATII inhibitors }\end{array}$ & $\begin{array}{l}\leq 8 \text { weeks after admission or first } \\
\text { outpatient contact }\end{array}$ & Process & $\geq 90$ \\
\hline & $\begin{array}{l}\text { Proportion of patients with reduced systolic function } \\
\text { (LVEF } \leq 40 \% \text { ) treated with beta-blockers }\end{array}$ & $\begin{array}{l}\leq 12 \text { after admission or first outpatient } \\
\text { contact }\end{array}$ & Process & $\geq 80$ \\
\hline & $\begin{array}{l}\text { Proportion of patients with reduced systolic function } \\
\text { (LVEF } \leq 35 \%) \text { treated with MRA }\end{array}$ & $\begin{array}{l}\leq 12 \text { weeks after admission or first } \\
\text { outpatient contact }\end{array}$ & Process & $\geq 35$ \\
\hline Physical training & $\begin{array}{l}\text { Proportion of patients with reduced systolic function } \\
\text { (LVEF } \leq 40 \% \text { ) referred to individual physical training }\end{array}$ & $\begin{array}{l}\leq 12 \text { weeks after admission or first } \\
\text { outpatient contact }\end{array}$ & Process & $\geq 30$ \\
\hline Patient education & $\begin{array}{l}\text { Proportion of patients with reduced systolic function } \\
\text { (LVEF } \leq 40 \% \text { ) who were started on a structured } \\
\text { patient education }\end{array}$ & $\begin{array}{l}\leq 12 \text { weeks after admission or first } \\
\text { outpatient contact }\end{array}$ & Process & $\geq 80$ \\
\hline Readmission & $\begin{array}{l}\text { Proportion of patients hospitalized acutely within } \\
4 \text { weeks after discharge or first outpatient contact }\end{array}$ & $\begin{array}{l}\leq 4 \text { weeks after discharge from the } \\
\text { hospital or first outpatient contact }\end{array}$ & Outcome & $\leq 10$ \\
\hline Mortality & $\begin{array}{l}\text { Proportion of patients who die I year after } \\
\text { admission to hospital or first outpatient contact }\end{array}$ & $\begin{array}{l}\leq \mathrm{I} \text { year after admission or first } \\
\text { outpatient contact }\end{array}$ & Outcome & $\leq 20$ \\
\hline
\end{tabular}

Abbreviations: ACE/ATII, angiotensin converting enzyme/angiotensin II antagonist; LVEF, left ventricular ejection fraction; MRA, mineralocorticoid receptor antagonist; NYHA functional classification, New York Heart Association functional classification.

Table 3 Coverage and completeness of indicator variables and prognostic factors 2004 to 2015

\begin{tabular}{|c|c|c|c|c|c|c|c|c|c|c|c|c|}
\hline Annual report, year & 2004 & 2005 & 2006 & 2007 & 2008 & 2009 & 2010 & 2011 & 2012 & 2013 & 2014 & 2015 \\
\hline Number of patients & 2,598 & 2,452 & 2,429 & 2,731 & 2,996 & 3,229 & 3,447 & 3,876 & 3,909 & 3,957 & 3,631 & 3,735 \\
\hline Coverage, national level (\%) & na & $76^{*}$ & $69 *$ & $73^{*}$ & $72^{* *}$ & 79 & 84 & 82 & 83 & 84 & 81 & 82 \\
\hline \multicolumn{13}{|c|}{ Completeness of indicator variables $* * *(\%)$} \\
\hline Echocardiography & 94 & 100 & 100 & 100 & 100 & 99 & 100 & 99 & 100 & 100 & 100 & 100 \\
\hline NYHA functional classification & 94 & 100 & 100 & 100 & 99 & 100 & 100 & 100 & 100 & 100 & 100 & 100 \\
\hline ACE/ATII inhibitors & na & 67 & 81 & 85 & 85 & 87 & 86 & 89 & 92 & 93 & 93 & 94 \\
\hline Beta-blockers & na & 36 & 52 & 60 & 87 & 90 & 87 & 89 & 92 & 93 & 93 & 94 \\
\hline MRA & na & 6 & 17 & 24 & 85 & 89 & 86 & 87 & 90 & 90 & 91 & 92 \\
\hline Physical training & 51 & 68 & 83 & 83 & 86 & 87 & 84 & 87 & 89 & 89 & 88 & 91 \\
\hline Patient education & 63 & 78 & 89 & 88 & 87 & 88 & 85 & 88 & 91 & 91 & 92 & 93 \\
\hline Readmission & na & 100 & 100 & 100 & 99 & 100 & 100 & 99 & 99 & 100 & 100 & 100 \\
\hline Mortality & na & 100 & 100 & 100 & 100 & 100 & 100 & 100 & 100 & 100 & 100 & 100 \\
\hline \multicolumn{13}{|c|}{ Completeness of prognostic factors (\%) } \\
\hline Smoking & na & na & 79 & 82 & 85 & 84 & 86 & 88 & 89 & 92 & 93 & 92 \\
\hline Alcohol & na & na & 71 & 75 & 78 & 80 & 82 & 83 & 85 & 89 & 88 & 89 \\
\hline LVEF & 72 & 73 & 81 & 86 & 90 & 92 & 93 & 97 & 98 & 99 & 99 & 99 \\
\hline Creatinine & na & na & na & na & na & na & 100 & 100 & 100 & 100 & 100 & 98 \\
\hline AMI & 80 & 81 & 89 & 92 & 98 & 98 & 98 & 99 & 98 & 99 & 99 & 99 \\
\hline Stroke & 72 & 72 & 85 & 88 & 98 & 98 & 98 & 99 & 98 & 98 & 98 & 98 \\
\hline Hypertension & 76 & 77 & 87 & 91 & 99 & 99 & 99 & 99 & 99 & 99 & 99 & 99 \\
\hline COPD & 71 & 72 & 85 & 88 & 98 & 98 & 98 & 99 & 98 & 99 & 99 & 98 \\
\hline Diabetes & 76 & 77 & 89 & 93 & 99 & 99 & 99 & 99 & 99 & 99 & 99 & 99 \\
\hline
\end{tabular}

Notes: *Self-reported coverage. From 2009, coverage is estimated from the registration of patients in the Danish National Patient Register. **Self-reported coverage. In 2008, coverage was also estimated from the Danish National Patient Register, reaching only $43 \%$.***Data completeness refers to whether or not all the information necessary to estimate the indicator was available in the data resource.

Abbreviations: ACE/ATII, angiotensin converting enzyme/angiotensin II antagonist; AMI, acute myocardial infarction; COPD, chronic obstructive pulmonary disease; LVEF, left ventricular ejection fraction; MRA, mineralocorticoid receptor antagonist; na, not available; NYHA functional classification, New York Heart Association functional classification. 
effort by the departments is performed to review the lists of inpatients and outpatients with the primary diagnosis of HF and to assess whether the inclusion and exclusion criteria in the DHFR are fulfilled.

\section{Follow-up}

Six of the seven indicators selected in the DHFR are related to care processes and outcome within a period of 12 weeks from the date for first contact to either hospital or outpatient clinic. Information on the seventh indicator on 1-year mortality is obtained from the Danish Civil Registration System, ${ }^{10}$ where vital status is updated continuously.

The participating departments receive regular feedback on their performance regarding the process indicators to ensure data validation and to support quality improvement.

\section{Examples of research}

The population-based data and a high number of patients with incident systolic and nonsystolic HF makes the DHFR data suitable for clinical epidemiology research. A study has shown a substantial improvement in the DHFR process indicators from 2003 to 2010 among patients diagnosed with incident HF. In the same period, the 1-year mortality decreased from $20.5 \%$ to $12.8 \%$. $^{11}$

An analysis based on the DHFR and demographic data indicates that HF is not diagnosed and treated adequately in people above 75 years. ${ }^{12}$ Studies on patients with systolic $\mathrm{HF}$ in the DHFR indicate equal effect of different types of angiotensin converting enzyme inhibitors and beta-blockers on mortality in patients with HF. ${ }^{13,14}$

\section{Administrative issues and funding}

The DHFR is funded and operated by the Danish Clinical Registries, ${ }^{15}$ which are financed and owned by the five Danish regions. A clinical epidemiologist and a quality consultant from the Danish Clinical Registries are affiliated to the DHFR. The epidemiologist has the responsibility for the analytical methods, analysis of data, and interpretation of results in the DHFR. The quality consultant is responsible for communication and support to the DHFR as well as communication with the participating hospitals.

\section{Conclusion}

The DHFR is a valuable tool for improving the quality of care for patients with $\mathrm{HF}$ and a valuable source for research. Since the establishment in 2003, the care of patients with incident HF admitted to the Danish hospitals and registered in the DHFR has improved with a higher level of achievement of quality indicators and declining 1 -year mortality.

\section{Acknowledgments}

The DHFR exists only due to the continued efforts and contributions from the staff working with patients with HF. This paper was funded by the Program for Clinical Research Infrastructure (PROCRIN) established by the Lundbeck Foundation and the Novo Nordisk Foundation and administered by the Danish regions.

\section{Disclosure}

The authors report no conflicts of interest in this work.

\section{References}

1. Mainz J, Hansen AM, Palshof T, Bartels PD. National quality measurement using clinical indicators: The Danish National Indicator Project. J Surg Oncol. 2009;99(8):500-504.

2. McMurray JJ, Adamopoulos S, Anker SD, et al. ESC guidelines for the diagnosis and treatment of acute and chronic heart failure 2012: the task force for the diagnosis and treatment of acute and chronic heart failure 2012 of the European Society of Cardiology. Developed in collaboration with the Heart Failure Association (HFA) of the ESC. Eur J Heart Fail. 2012;14(8):803-869.

3. Mainz J. Defining and classifying clinical indicators for quality improvement. Int J Qual Health Care. 2003;15(6):523-530.

4. Nielsen OW, Egstrup K, Køber L; for Danish Society of Cardiology National cardiologisk behandlingsvejledning (NBV), 5. kronisk hjertesvigt (National guidelines in cardiology (NBV), 5. Chronic Heart Failure Updated June 2015). Available from: http://nbv.cardio.dk/chf. Accessed July 13, 2015.

5. Yancy CW, Jessup M, Bozkurt B, et al. 2013 ACCF/AHA guideline for the management of heart failure: a report of the American College of Cardiology Foundation/American Heart Association Task Force on Practice Guidelines. J Am Coll Cardiol. 2013;62(16):e147-e239.

6. Registry Support Centre of Clinical Quality and Health Informatics (West). Datadefinitioner for NIP-hjerteinsufficiens (Data definitions for NIP-Heart Failure (The Heart Failure Registry)). Available from: http:// www.kcks-vest.dk/kliniske-kvalitetsdatabaser/hjertesvigt/. Accessed December 6, 2015. [Danish].

7. Dansk Hjertesvigtdatabase. Dokumentalistrapport, Version 1, August 2015 (Manual for the Danish Heart Failure registry, August 2015). Available from: http://www.kcks-vest.dk/kliniske-kvalitetsdatabaser/ hjertesvigt. 2015. [Danish]. Accessed April 8, 2016.

8. Dansk Hjertesvigtdatabase (DHD). National årsrapport 2015,1. juli 2014 - 30. juni 2015. 2015. (Danish Heart Failure Registry (DHFR) National annual report 2015, July 1, 2014-June 30, 2015). Available from: https://www.sundhed.dk/sundhedsfaglig/kvalitet/kliniskekvalitetsdatabaser/hjerte-kar-sygdomme/hjertesvigt-nip/. Accessed February 18, 2016. [Danish].

9. Schmidt M, Schmidt SA, Sandegaard JL, Ehrenstein V, Pedersen L, Sorensen HT. The Danish National Patient Registry: a review of content, data quality, and research potential. Clin Epidemiol. 2015;7:449-490. doi: 10.2147/CLEP.S91125.

10. Schmidt M, Pedersen L, Sorensen HT. The Danish Civil Registration System as a tool in epidemiology. Eur J Epidemiol. 2014;29(8):541-549. doi: 10.1007/s10654-014-9930-3. 
11. Nakano A, Johnsen SP, Frederiksen BL, et al. Trends in quality of care among patients with incident heart failure in Denmark 2003-2010: a nationwide cohort study. BMC Health Serv Res. 2013;13:391. Available from: http://www.biomedcentral.com/1472-6963/13/391. Accessed December 6, 2015.

12. Olesen LL. Dansk Hjertesvigts Database tyder på underrapportering og underbehandling blandt ældre (The Danish National Quality Project about heart failure indicates lack of reporting and treatment of the elderly). Ugeskr Laeger. 2014;176(39). pii: V05140288. [Danish].
13. Svanstrom H, Pasternak B, Melbye M, Hviid A. Use of different types of angiotensin converting enzyme inhibitors and mortality in systolic heart failure. Int J Cardiol. 2015;182:90-96.

14. Pasternak B, Mattsson A, Svanstrom H, Hviid A. Comparative effectiveness of bisoprolol and metoprolol succinate in patients with heart failure. Int J Cardiol. 2015;190:4-6.

15. Danish Quality Improvement Program (RKKP). Internet homepage. Available from: http://www.rkkp.dk/in-english/. Accessed December 6, 2015. [Danish].

\section{Publish your work in this journal}

Clinical Epidemiology is an international, peer-reviewed, open access, online journal focusing on disease and drug epidemiology, identification of risk factors and screening procedures to develop optimal preventative initiatives and programs. Specific topics include: diagnosis, prognosis, treatment, screening, prevention, risk factor modification,

Submit your manuscript here: http://www.dovepress.com/clinical-epidemiology-journal

\section{Dovepress}

systematic reviews, risk \& safety of medical interventions, epidemiology \& biostatistical methods, and evaluation of guidelines, translational medicine, health policies \& economic evaluations. The manuscript management system is completely online and includes a very quick and fair peer-review system, which is all easy to use. 